\title{
Kajian Etik Pendidikan Jarak Jauh dalam Pendidikan Kedokteran di Indonesia
}

\author{
Anna Rozaliyani ${ }^{1,2}$, Hansel Tengara Widjaja, Pukovisa Prawiroharjo ${ }^{1,3}$, Wawang Sukarya ${ }^{1,4}$ \\ ${ }^{\mathrm{I}}$ Majelis Kehormatan Etik Kedokteran Pengurus Besar Ikatan Dokter Indonesia \\ ${ }^{2}$ Departemen Parasitologi Fakultas Kedokteran Universitas Indonesia \\ ${ }^{3}$ Departemen Neurologi Fakultas Kedokteran Universitas Indonesia/Rumah Sakit Cipto Mangunkusumo \\ 4Departemen Obstetri dan Ginekologi, Fakultas Kedokteran Universitas Islam Bandung, Bandung
}

\author{
Kata Kunci \\ Etika, pendidikan jarak jauh (PJJ), \\ pendidikan kedokteran, pandemi \\ COVID-i9 \\ Korespondensi \\ anna.rozaliyani@ui.ac.id \\ Publikasi \\ (C) 2020 JEKI/ilmiah.id \\ DOI \\ I0.26880/jeki.v4i2.49 \\ Tanggal masuk: 27 Juni 2020 \\ Tanggal ditelaah: 27 Agustus 2020 \\ Tanggal diterima: 2 September 2020 \\ Tanggal publikasi: 4 September 2020
}

\begin{abstract}
Abstrak Sejak awal tahun 2020, dunia telah dikejutkan dengan pandemi COVID-I9. COVID-i9 telah menyebabkan perubahan yang fundamental terhadap segala segi kehidupan, termasuk dalam pendidikan kedokteran. Apabila kita menilik sejarah pendidikan kedokteran di Indonesia, peristiwa wabah juga menjadi tonggak dimulainya pendidikan kedokteran di Indonesia. Di dunia, pandemi flu Spanyol juga telah mengubah pendidikan kedokteran di kala itu. Dengan kemajuan teknologi, pendidikan kedokteran di masa pandemi ini dilaksanakan dalam bentuk pendidikan jarak jauh (PJJ). Meskipun demikian, tidak dipungkiri dampaknya terhadap pemenuhan kompetensi yang semakin sulit. Memperpanjang durasi pendidikan kedokteran tampaknya menjadi solusi yang ideal, namun juga menambahkan beban staf pendidik dan peserta didik. Dalam menentukan pilihan yang akan diambil oleh pembuat kebijakan pendidikan kedokteran perlu dipertimbangkan risk-versusbenefit serta konsekuensinya masing-masing.
\end{abstract}

Abstract Since March 2020, the world has been battling COVID-I9 pandemic. This pandemic has fundamentally changed every aspect of our lives. One of the aspects also affected by the pandemic is medical education. In the history of medical education in Indonesia, medical education of native doctors was also initiated by an outbreak. During the spanish flu pandemic more than one hundred years ago, there was a radical revolution in medical education system to help combat the pandemic. With advances in technology, the method of medical education has shifted to utilizing online platforms. However, we have to acknowledge that not all competencies can be achieved by such method. On the other hand, by extending the period of medical study to fulfill all competencies, it will increase the burden of the lecturers and students. In conclusion, all stake holders must contemplate on the risk and benefit of every decision they made, with the consequences it brings.

Awal tahun 2020 ini dunia dikejutkan dengan munculnya wabah penyakit yang disebabkan infeksi virus SARS-CoV-2. Wabah bermula dari Tiongkok pada akhir Desember 2019, dan WHO telah menyatakan wabah tersebut sebagai pandemi sejak 11 Maret 2020. ${ }^{1}$ Indonesia tak luput dari imbas pandemi tersebut, sehingga Presiden membentuk Gugus Tugas Percepatan Penanganan COVID-19 pada 13 Maret 2020. Kondisi pandemi sekaligus membawa perubahan pola hidup yang mendasar, antara lain diberlakukannya pembatasan sosial dan fisik guna mencegah penyebaran COVID-19. ${ }^{2}$ Salah satu bidang yang terimbas kebijakan tersebut adalah dunia pendidikan kedokteran. Pada bagian selanjutnya akan dibahas mengenai kajian etik kebijakan Pendidikan Jarak Jauh (PJJ) dalam konteks pandemi COVID-19.

\section{Pendidikan Kedokteran di Indonesia}

Momentum pendidikan kedokteran di Indonesia lahir pada 2 Januari 1849, yang diprakarsai oleh Keputusan Gubernemen Batavia, pemerintah Hindia Belanda No. 22. Pendidikan itu dilangsungkan di Rumah Sakit Militer (sekarang RSPAD). Kala itu, pendidikan kedokteran dibuat guna memenuhi kebutuhan masyarakat karena timbulnya wabah cacar. Pada tanggal 5 Juni 1853, kursus juru kesehatan ini kemudian ditingkatkan oleh Surat Keputusan Gubernemen Batavia, pemerintah Hindia Belanda No. 10 dan diakui sebagai proses pendidikan kedokteran yang disebut Sekolah Dokter Djawa, dengan masa pendidikan saat itu adalah tiga tahun. Lulusan sekolah ini berhak 
bergelar "Dokter Djawa", meskipun pada prakteknya saat itu lebih menyerupai mantri penyakit cacar. Walau diberi gelar dokter, lulusan sekolah itu hanya memiliki kewenangan seperti mantri, dan diperkerjakan sebagai mantri cacar. Setelah 20 tahun, sekolah pendidikan kedokteran yang sesungguhnya berdiri, hingga kemudian pada tahun 1898 nama "Sekolah Dokter Djawa" diubah menjadi "School tot Opening van Inlandsche Artsen" (sekolah dokter pribumi) atau disingkat STOVIA. Pada tahun 1913, kata "Inlandsche" (pribumi) kemudian diubah menjadi Indische (Hindia) sehingga menjadi terbuka untuk dimasuki siapa saja, termasuk penduduk keturunan Timur Asing dan Eropa. ${ }^{3,4}$ Saat ini, STOVIA telah menjadi Fakultas Kedokteran Universitas Indonesia. ${ }^{4}$

Seiring berkembangnya zaman, pendidikan kedokteran di Indonesia terus berkembang menjadi pendidikan yang lebih terstruktur, terdiri atas tahap preklinik dan tahap klinik. Pada tahun 1981 telah disusun kurikulum pendidikan kedokteran di Indonesia (KIPDI), dengan peresmian KIPDI I oleh Konsorsium Ilmu Kesehatan Indonesia pada tahun 1982. Saat ini kurikulum yang berjalan adalah KIPDI IV, yang berasaskan pada pendidikan berbasis kompetensi. ${ }^{4,5}$

Pendidikan berbasis kompetensi mendorong integrasi antara ilmu kedokteran dasar dan ilmu kedokteran klinis. Selain itu, mahasiswa preklinik juga sudah diperkenalkan ilmu keterampilan klinis sejak masa pendidikan preklinik. ${ }^{5}$ Dengan kemajuan teknologi pula, pendidikan kedokteran telah bermetamorfosis dari sumber ilmu berbasis kertas menjadi berbasis elektronik. Kuliah yang biasa dilaksanakan secara tatap muka, kini mulai disampaikan dalam bentuk digital, sehingga dapat disimak setiap saat dan di mana pun mahasiswa berada. ${ }^{5}$

Selain perubahan tersebut, aspek pendidikan kedokteran yang tidak berubah adalah pengetahuan komprehensif, keterampilan, dan profesionalisme. Pengetahuan mencakup segala aspek kognitif yang diperoleh mahasiswa melalui kuliah interaktif, kegiatan pembelajaran mandiri, dan diskusi kelompok. Aspek keterampilan mencakup kemampuan mahasiswa untuk melakukan prosedur klinis, ketangkasan menjalankan algoritma diagnosis dan tata laksana, serta keterampilan berkomunikasi. Aspek profesionalisme mencakup empati dan etika yang harus menjadi karakter kuat yang diterapkan sejak masa mahasiswa hingga kehidupannya kelak sebagai seorang dokter. ${ }^{5}$

\section{Perubahan Pelaksanaan Pendidikan Kedokteran akibat Pandemi COVID-19}

Terjadinya pandemi COVID-19 telah mengubah pelaksanaan pendidikan kedokteran secara fundamental. Kegiatan pendidikan yang bersifat tatap muka harus ditiadakan atau diganti dengan kegiatan serupa melalui media lain. Pelaksanaan kegiatan tatap muka di beberapa universitas telah diubah menjadi metode pendidikan jarak jauh (PJJ). ${ }^{6}$ Metode PJJ ini memanfaatkan teknologi berupa media pembelajaran daring yang dimiliki fakultas sebagai media komunikasi virtual untuk menunjang pendidikan. Hal itu menjadi tantangan dalam memenuhi seluruh indikator pencapaian aspek pendidikan kedokteran.

Dengan media pembelajaran daring yang telah digunakan rutin oleh fakultas, akses mahasiswa untuk memperoleh materi terkait teori ilmu kedokteran dasar dan klinis tampaknya tidak menjadi kendala. Meskipun demikian, aspek keterampilan masih sulit terpenuhi dengan model PJJ karena diperlukan supervisi langsung oleh staf pengajar untuk memastikan terpenuhinya keterampilan mahasiswa. Kegiatan praktikum yang memerlukan alat dan bahan yang tidak dimiliki mahasiswa di rumah juga menjadi kendala berikutnya. Dalam aspek profesionalisme, peran staf pengajar dan institusi pendidikan sangat penting sebagai role model, teladan yang baik bagi mahasiswa. Evaluasi aspek profesionalisme juga menjadi sulit karena pembatasan sosial dan fisik yang diterapkan selama pandemi.

Beberapa solusi yang telah diupayakan misalnya membuat video percobaan untuk menunjang kegiatan praktikum mahasiswa. Namun demikian, beberapa hal masih belum dapat digantikan dengan metode PJJ, yaitu interaksi langsung dengan pasien untuk 
memperoleh data objektif sebagai bagian dari keterampilan klinis. Selain itu, beberapa prosedur keterampilan klinis juga memerlukan supervisi yang rinci dari staf pendidik, sehingga tidak dapat digantikan dengan metode PJJ. Adapun untuk mencapai kemampuan penalaran klinis, dengan metode PJJ yang tepat dapat membantu pencapaian penalaran klinis peserta didik. Meskipun demikian, terdapat penelitian yang mengungkapkan bahwa capaian akhir dan kepuasan peserta didik antara kelompok diskusi simulasi lebih rendah dibandingkan dengan diskusi kasus langsung. ${ }^{7,8}$

Perubahan pelaksanaan pendidikan kedokteran dengan metode PJJ merupakan suatu tantangan baru. Beberapa aspek pendidikan kedokteran yang perlu dicapai, misalnya keterampilan klinis, pengalaman klinis dengan pasien, dan aspek profesionalisme, masih sulit digantikan dengan metode PJJ. Metode evaluasi berupa Objective Structured Clinical Examination (OSCE) dan ujian klinis berbasis pasien juga menjadi sulit dilaksanakan mengingat adanya pembatasan sosial. Hal itu menunjukkan bahwa selain munculnya kesulitan dalam mencapai standar kompetensi dokter Indonesia, metode evaluasi untuk menilai tercapainya kompetensi tersebut juga masih menjadi kendala serius.

\section{Dilema etik yang dihadapi pembuat kebijakan pendidikan kedokteran}

Metode PJJ belum terbukti efektif untuk mencapai tujuan pendidikan kedokteran karena berbagai keterbatasan. Kompetensi lulusan dokter berpotensi sulit dinilai secara objektif bila diukur menggunakan metode yang dilaksanakan sebelum masa pandemi. Kondisi ini juga berpotensi mengancam profesionalisme lulusan dokter yang menjalani pendidikan kedokteran pada masa pandemi. Hal itu tidak selaras dengan Kode Etik Kedokteran Indonesia (KODEKI) Pasal 8.9

Pada Pasal 8 KODEKI: Profesionalisme, "Seorang dokter wajib, dalam setiap praktik medisnya, memberikan pelayanan secara berkompeten dengan kebebasan teknis dan moral sepenuhnya, disertai rasa kasih sayang (compassion) dan penghormatan atas martabat manusia". Dijelaskan dalam Cakupan Pasalnya, "Seorang dokter yang akan menjalankan praktek wajib memiliki kompetensi dan kewenangan sesuai ketentuan yang berlaku sebagai prasyarat sekaligus kesinambungan profesionalisme".

Urutan kontinuum profesionalisme dokter dalam pelayanan profesinya dimulai dari diperolehnya kompetensi sebagai hasil pendidikan dan pelatihan, kredensial, dan peningkatan mutu yang senantiasa berkembang sesuai dinamika kebutuhan masyarakat. Hal ini diikuti perolehan kewenangan yang diberikan negara sebagai bentuk pengaturan perizinan profesi untuk dilapis oleh 'pakaian' profesionalisme dalam pelaksanaan profesi. Profesionalisme hakikatnya adalah cerminan etika sebagai tekad profesi untuk melayani yang terbaik bagi pasien, menuju trias keluaran sistem etikolegal yakni: tujuan medik, keselamatan pasien, dan terjaganya martabat profesi. ${ }^{9}$

$$
\text { Pada konteks pandemi COVID-19, }
$$
kebijakan pembatasan sosial dan fisik merupakan hal yang sangat penting dalam memutus rantai penularan. Hal itu mengingat sebagian orang yang telah terinfeksi virus SARS-CoV-2 dapat tidak bergejala. Dengan demikian, apabila pendidikan kedokteran tetap dilaksanakan secara off-line (tatap muka langsung), maka ada kemungkinan bahwa mahasiswa kedokteran yang menjalani praktik klinik dapat secara tidak disadari menularkan COVID-19 kepada pasien yang diperiksa, atau sebaliknya. Pada kondisi tersebut, mahasiswa kedokteran secara tak disadari berpotensi melakukan harm terhadap pasien, yang tentu melanggar kaidah dasar bioetika. ${ }^{10}$

\section{Alternatif solusi yang dapat dilaksanakan}

Pandemi COVID-19 merupakan masalah bersama sehingga seluruh pihak, termasuk dunia pendidikan kedokteran, harus mengutamakan kepentingan penyelesaian masalah pandemi ini. Kondisi tersebut menjadi prioritas utama dibandingkan 'sekedar' pemenuhan kompetensi dokter, terlebih lagi bahwa dengan kebutuhan pembatasan kontak fisik (physical distancing). ${ }^{2}$

Beberapa hal yang harus dipertimbangkan adalah:

1. Apakah institusi pendidikan kedokteran dapat menjamin kompetensi peserta didiknya, sementara harus diakui PJJ juga 
mengalami keterbatasan?

2. Bagaimana tanggung jawab institusi pendidikan kedokteran mewariskan semangat jiwa kemanusiaan dari peserta didik jika mereka lama dibelenggu dengan aktivitas PJJ tanpa dapat memberi sumbangsih apapun, sementara di sisi lain terdapat kabar kesulitan hingga kabar duka cita atas meninggalnya dokter-dokter di lapangan yang melakukan pelayanan kesehatan di era pandemi terus berdatangan? Terkait masalah kompetensi dokter, beberapa fakultas kedokteran di negara lain, misalnya Amerika Serikat dan Eropa, telah mengubah skema pendidikan agar mahasiswa kedokterandapatdiluluskanlebihcepat, sehingga dapat turut menangani pandemi COVID-19.11-13 Hal serupa terjadi saat pandemi flu Spanyol satu abad silam. ${ }^{11}$ Masalah profesionalisme terkait kompetensi dokter harus disesuaikan dengan kondisi pandemi, mengingat seluruh dokter harus dapat menangani pandemi yang semakin hari semakin bertambah kasusnya.

Dengan mempercepat kelulusan dokter, kompetensi utama yang diprioritaskan pada saat pendidikan mestinya lebih difokuskan pada penanganan kasus pandemi. Dibandingkan dengan tetap melaksanakan pendidikan kedokteran dengan metode PJJ yang juga tidak menjamin tercapainya kompetensi ideal, maka mempercepat kelulusan dokter mungkin dapat menjadi pilihan yang baik, terutama di saat tenaga dokter sangat diperlukan. Untuk tetap menjamin kompetensi lulusan dokter setelah mereka turut terjun dalam penanganan pandemi sebagai seorang dokter yang diberi wewenang atau setidaknya calon dokter yang dilakukan supervisi oleh dokter, dapat dokter tersebut dapat difasilitasi dengan kursus jangka pendek untuk memenuhi kompetensi dokter yang tidak didapatkan karena kondisi pandemi.

Pilihan lain yang dapat dipertimbangkan adalah memperpanjang masa studi untuk mencapai kompetensi yang tidak tercapai selama pandemi. Pilihan ini tampaknya ideal, namun berdampak pada bertambahnya beban pendidikan yang harus ditanggung staf pendidik (dosen) dan mahasiswa. Pilihan ideal ini mungkin juga akan tidak tercapai, apabila pandemi tidak kunjung terkendali.

Terkait dengan pendidikan tahap preklinik, aspek kognitif dapat saja dilaksanakan dengan metode PJJ. Meskipun demikian, aspek psikomotor dan afektif sulit untuk dapat dilaksanakan dengan metode PJJ, karena diperlukannya kontak langsung antara pengajar dengan mahasiswa agar transfer kompetensi ini dapat terjadi. Oleh karena itu, tidak serta merta pendidikan kedokteran dapat dilaksanakan seluruhnya dengan metode PJJ.

Apapun pilihan yang akan ditentukan oleh penentu kebijakan, maka harus dilakukan analisis yang matang dan mendalam mengenai risk dan benefit dari setiap pilihan tersebut. Perlu diingat bahwa pelaksanaan protokol pencegahan dan pengendalian COVID-19 juga perlu dilaksanakan guna melindungi para dosen dan peserta didik. Keterbukaan dalam proses pengambilan kebijakan juga penting, mengingat kegiatan pendidikan kedokteran tidak terlepas dari kondisi di lapangan. Pembuat kebijakan juga harus cepat beradaptasi dengan situasi yang dapat berubah setiap saat, serta memberikan pertimbangan yang tegas dan jelas agar capaian pendidikan kedokteran tetap dapat diupayakan secara optimal.

\section{KESIMPULAN}

Pendidikan kedokteran tak terlepas dari dampak pandemi COVID-19. Ketentuan pembatasan sosial dan fisik guna memutus mata rantai penulatan COVID-19 terpaksa mengubah pelaksanaan pendidikan kedokteran menjadi metode PJJ. Keterbatasan metode PJJ berkaitan dengan pemenuhan standar kompetensi dokter yang tidak ideal, terutama pada aspek keterampilan dan pengalaman klinis. Hal itu juga mengancam profesionalisme dokter yang akan lulus dalam masa pandemi. Oleh karena itu, dapat dilakukan beberapa alternatif solusi, seperti mempercepat kelulusan mahasiswa kedokteran guna menangani masalah bersama yang makin memburuk, maupun memperpanjang waktu pendidikan kedokteran guna memenuhi standar kompetensi dokter indonesia. Apapun pilihan yang ditentukan kemudian, perlu dipertimbangkan risk dan benefit 
serta konsekuensinya. Selain itu, perlu diingat bahwa kebijakan harus tetap memperhatikan kondisi yang terjadi di lapangan dan mengimplementasikan protokol pencegahan dan pengendalian COVID-19. Layaknya peristiwa revolusioner dalam pendidikan kedokteran yang pernah terjadi dalam sejarah, pembuat kebijakan pendidikan kedokteran juga harus senantiasa cepat beradaptasi dengan situasi dan memberikan pertimbangan yang tegas dan jelas guna memaksimalkan potensi pendidikan kedokteran pada kondisi ini.

\section{KONFLIK KEPENTINGAN}

Tidak ada konflik kepentingan.

\section{UCAPAN TERIMA KASIH}

Penulis ingin memberikan ucapan terima kasih kepada iMuseum IMERI atas bantuannya memberikan referensi sejarah pendidikan kedokteran di Indonesia.

\section{REFERENSI}

1. World Health Organization. Coronavirus disease (COVID-19) Situation Reports [Internet].2020[cited2020May 16].Available from: https://www.who.int/emergencies/ diseases/novel-coronavirus-2019/situationreports/

2. World Health Organization. Coronavirus disease (COVID-19) advice for the public [Internet].2020[cited2020May 16]. Available from: https://www.who.int/emergencies/ diseases/novel-coronavirus-2019/advice-forpublic.

3. Hesselink L. Healers on the colonial market; Native doctors and midwives in the Dutch East Indiesnull [Internet]. Brill PP - Leiden - Boston; 2011. Available from: https:// library.oapen.org/bitstream/id/081aba28af8e-4a5a-b7b6-f3dd9669a3eb/400271.pdf

4. Perkumpulan Sejarah Kedokteran Indonesia. Sejarah Dan Direktori Pendidikan Kedokteran Di Indonesia:
1849-2017. 1st ed. Jakarta: PERSEKIN; 2017. p.10-21.

5. Konsorsium Ilmu Kesehatan. Perkembangan pendidikan kedokteran di Indonesia: Sistem Pendidikan Kedokteran di Indonesia menuju 2045. 1st ed. Indonesia: Konsorsium Ilmu Kesehatan; 2013.

6. Keputusan Bersama Kementerian Pendidikan dan Kebudayaan, Kementerian Agama, Kementerian Kesehatan, dan Kementerian Dalam Negeri. Panduan Penyelengaraan Pembelajaran pada Tahun Ajaran dan Tahun Akademik Baru di Masa Pandemi Coronavirus Disease (COVID-19); Juni 2020.

7. Couto T, Farhat S, Geis G, Olsen O, Schvartsman C. High-fidelity simulation versus case-based discussion for teaching medical students in Brazil about pediatric emergencies. Clinics. 2015;70(6):393-399.

8. Bokken L, Rethans J, Scherpbier A, van der Vleuten C. Strengths and Weaknesses of Simulated and Real Patients in the Teaching of Skills to Medical Students: A Review. Simulation in Healthcare: The Journal of the Society for Simulation in Healthcare. 2008;3(3):161-169.

9. Pengurus Besar Ikatan Dokter Indonesia. Kode Etik Kedokteran Indonesia. Kode Etik Kedokteran Indonesia. 2012.

10. Beauchamp and Childress. Principles of biomedical ethics. 4th Ed. Oxford:1994.

11. Rose S. Medical Student Education in the Time of COVID-19. JAMA. 2020;323(21):2131-2132. doi:10.1001/ jama.2020.5227 available from: https:// jamanetwork.com/journals/jama/ fullarticle/2764138.

12. Miller DG, Pierson L, Doernberg S. The Role of Medical Students During the COVID-19 Pandemic. Ann Intern Med. 2020;173(2):145-146. doi:10.7326/M201281. 
13. Prescott JE. Important Guidance for Medical Students on Clinical Rotations During the Coronavirus (COVID-19) Outbreak | AAMC [Internet]. 2020 [cited 2020 Jun 20]. Available from: https://www. aamc.org/news-insights/press-releases/ important-guidance-medical-studentsclinical-rotations-during-coronavirus-covid19-outbreak 